\title{
GEOLOGICAL CHARACTERISTICS OF THE NEOGENE VOLCANIC PLUGS IN INLICE (KONYA) AREA, CENTRAL TURKEY
}

DOI: https://doi.org/10.18509/GBP210059k

UDC: $552.313 .08(560)$

\author{
Kerim Kocak \\ Konya Technical University, Turkey
}

\begin{abstract}
Around İnlice village (WSW of Konya), numerous volcanic plugs crop out as steep-sided conical hills within Neogene lava dome covered partially by nuée ardente deposits. Nine circular to ellipsoidal plugs have determined with heights ranging from a few meters to $>50$ meters, and hence creates usually visible topographic landscapes. Plug-4, tallest one, has a joint system developed typically in NE direction, which was cut by faults formed in $\mathrm{N}-\mathrm{S}$ direction. In spite of the intensive alteration, mineralogical and petrographical characteristics of the samples suggests that the plugs are composed of dacite-andesite. The samples have also mafic enclave and some disequilibrium structures such as sieve texture in plagioclase, and acicular apatites, suggesting magma mixing and mingling in their petrogenesis.
\end{abstract}

Keywords: Plug, volcanism, geology, Konya

\section{INTRODUCTION}

Volcanic plugs is tower like landforms containing an igneous core of an dormant volcano whose outer layers have eroded away [1]. The plugs usually create visible topographic landscapes which are identifiable from a distance due to the resistance of the intrusive igneous rocks to erosion. The plugs necks have been usually associated in the literature with necks [2]. But, the plugs vary from necks as they correspond to a solidified mass of magmatic rock filling a volcanic vent or crater [3], inferring a considerably shallower location. The conduit thickness affects the magma rate, even variations in conduit geometry can affect the duration of an eruption [2] and likewise whether an eruption will be restricted or widespread.

In Turkey, the existence of plug or neck are reported in several studies, though no study exists to determine their features and occurences; In Almus (Tokat; Pontides) and in Yildizeli (Sivas; CACC) areas, the Middle Eocene volcanism may form as trachytic dikes, plugs, and stocks [4]. In the Afyon volcanic province (eastern part of Western Anatolia), Middle Miocene volcanics form as dome/plug-shaped bodies with lamproitic composition [5]. Dom and volcanic neck also occur in Kurka-Afyon-Isparta volcanic province of Pliocene-Quaternary Gölcük volcanics [6]. From the Kiraz Basin of the Küçük Menderes Graben (Western Anatolia), Miocene High-K calc-alkaline porphyritic andesites occur either lava flows or high-level dykes or volcanic necks in west of Karaburç area [7]. At the western basin margin of the Erciyes depression, near the city of Kayseri, a Late Middle Miocene-Early Pliocene basaltic neck, which cuts across the basement rock and lower pyroclastite horizons [8].

Well-known plugs in the World are Devil's Tower, Kapsiki Peak (Cameroon), Sigiriya Rock Fortress (Sri Lanka) and Ship Rock (New Mexico). There are also ancient castles 
builded on a volcanic plug such as the Castle Rock in Edinburgh (Scotland), Deganwy Castle (Wales) and Trosky Castle (the Czech Republic).

\section{STUDY AREA}

The study area is located in central southern Anatolia, $\sim 50 \mathrm{~km}$ to Konya ( Figure 1, 2). Plugs and plug-like occurrences form in a valley as steep-sided conical hills (Figure 3,4) around Inlice village (WSW of Konya), in where extensive Neogene volcanism took place in the area from Late Miocene. (11.9 Ma, Sille volcanics) to Pliocene (3.35 Ma, Gevrekli dome). Various volcanic and volcano-sedimentary units form in the region, namely, ignimbrite, nuée ardentes, volcanic breccias, agglomerates, tuffs, tuffites, lava flows, lava domes, dikes and sill, with composition of rhyolite, dacite, andesite, trachyandesite, basaltic trachyandesite, basalts and lamprophyres e.g. [9-16]. In the area, the volcanism also leads to the development of some economic mineralizations, such as Doğanbey $\mathrm{Cu}-$ Mo porphyry and Inlice Au epithermal deposits [17-18].

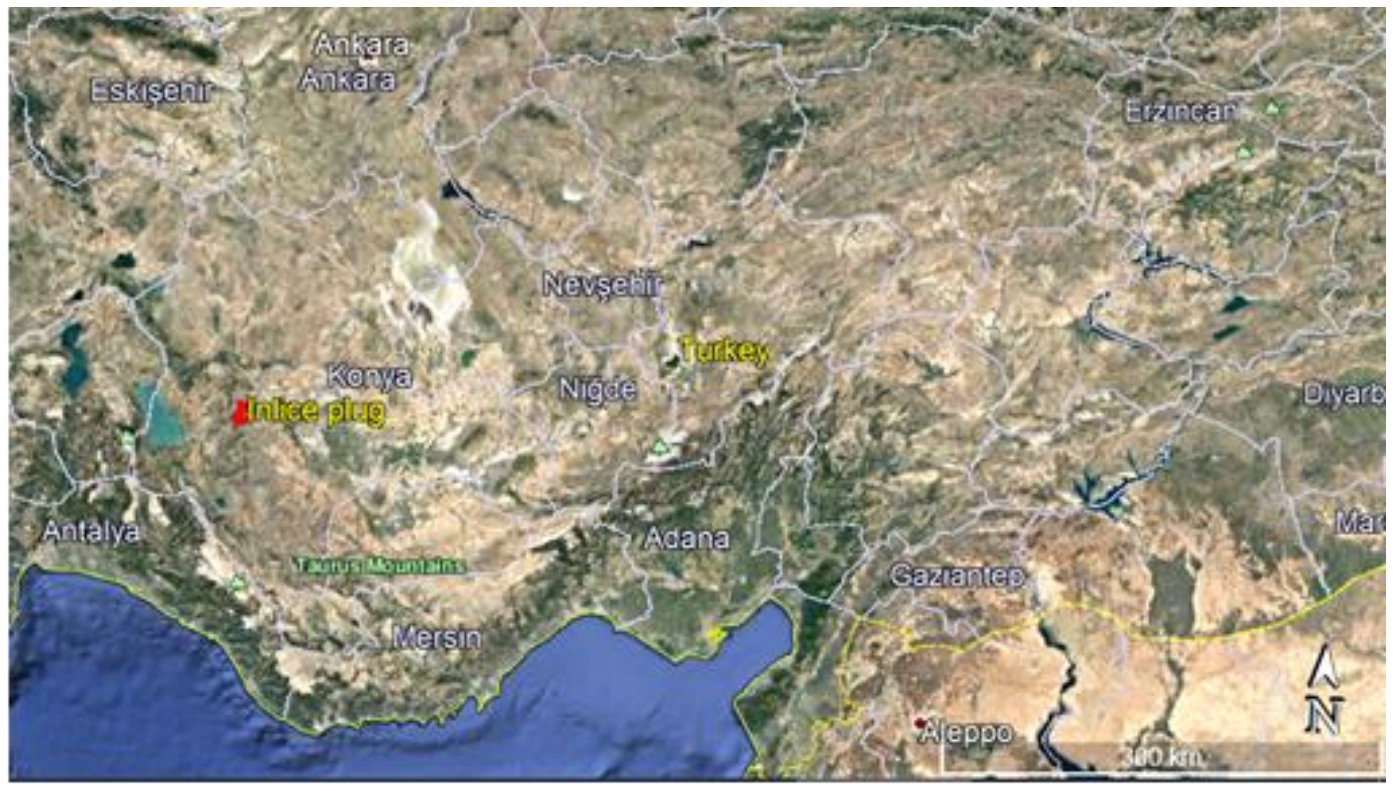

Figure 1: A Google map showing the location the studied plugs

The volcanic plug occurs within lava domes, which are suggested to be 10.9 to $3.35 \mathrm{Ma}$ [10]. Western part of Konya volcanics are the youngest lava domes of the studied area. The lava domes in Karadağ Tepe next to the study area, is one of the largest, are partially covered by nuée ardente deposits.

\section{METHODOLOGY AND DATA}

Field studies were performed in the region; all plug and plug-like samples were examined, and 46 samples were collected. Thin sections were prepared from fresh samples at thin section laboratory of the Geology Department in Konya Technical University (Turkey), to determine their mineralogical and petrographical characteristics under polarising microscope. Google Earth images were also used in studying the plugs to determine joints systems and faults.

Nine circular to ellipsoidal plugs have been identified in a small area, an area of 3.83 $\mathrm{km} 2$, (Figure 4). The plugs have height ranging from a few meters to $>50$ meters. A Google-Earth image of location-4, the tallest one, and -5 show that joint system may 
develop mostly in NE direction, which is cut predominantly by faults with N-S direction (Figure 5). The samples are light to dark grey in colour, and highly fractured due to joints and faults. It also contains mafic dark coloured enclave, indicating magma mingling.

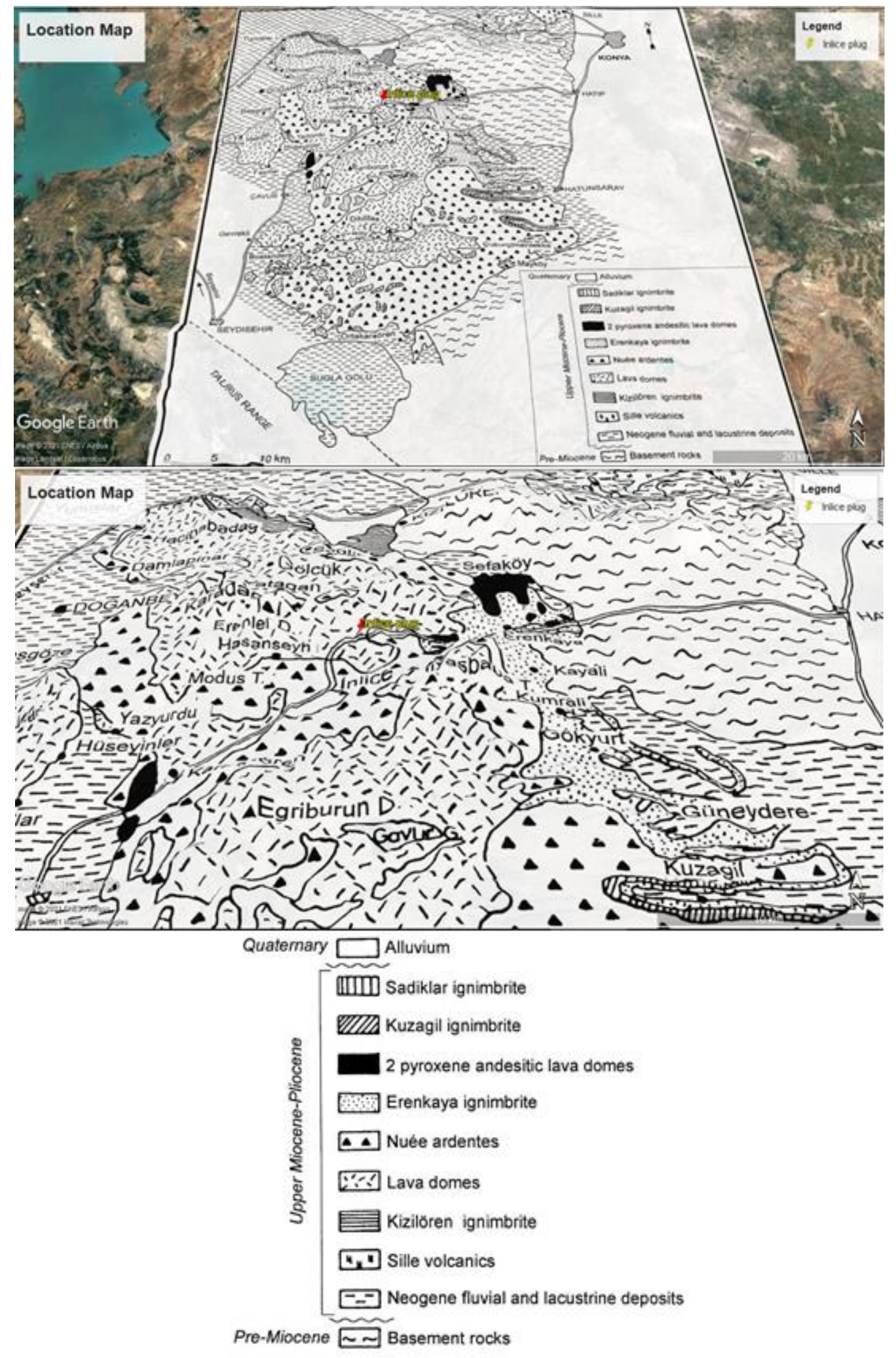

Figure 2: A Google Earth view and geological map of the area [9]. 



Figure 3: Google Earth view of the study area.

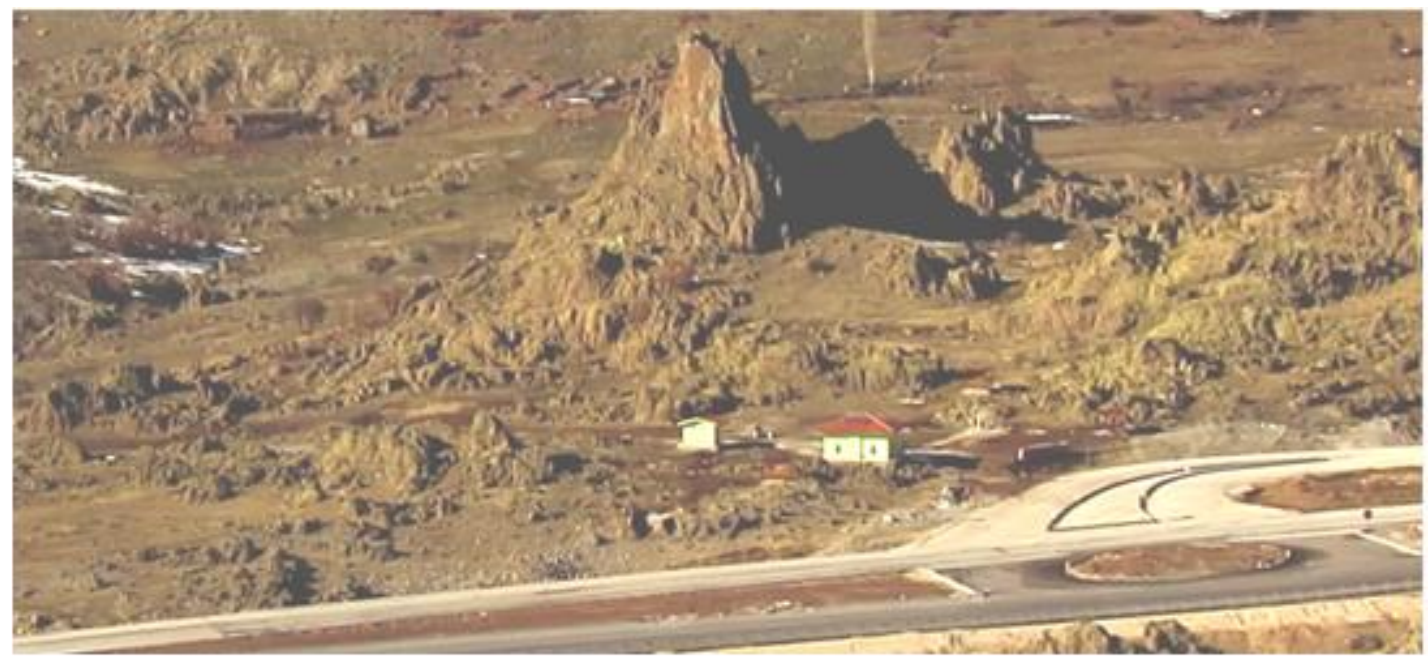

Figure 4: Location of the plugs -1-5. 

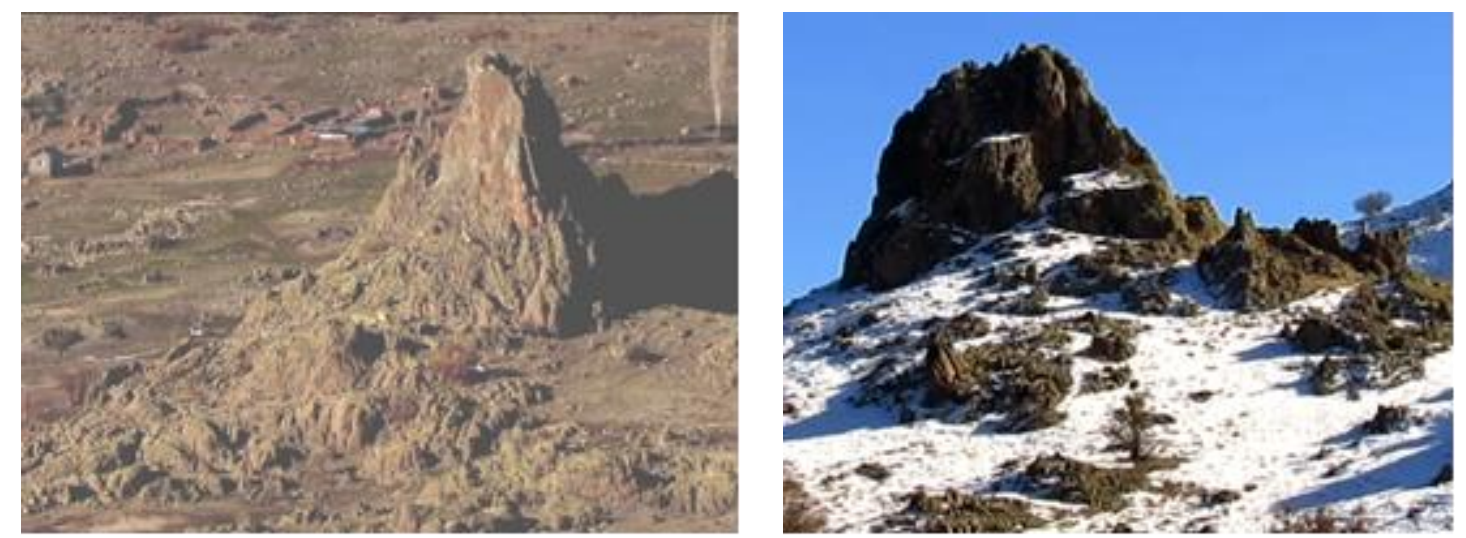

Figure 5: Field view of plugs-4(a) and 7 (b).



Figure 6: Joint and fault system in plug 4 .

Earth image of location-4, the tallest one, and -5 show that joint system may develop mostly in NE direction, which is cut predominantly by faults with N-S direction (Figure 5). The samples are light to dark grey in colour, and highly fractured due to joints and faults. It also contains mafic dark coloured enclave, indicating magma mingling

\section{PETROGRAPHY}

The plug samples have predominantly a hypocrystalline porphyric texture, including phenocryst of plagioclase (20-25\%), biotite (10\%), quartz (1-2\%), amphibole (1-2\%) and opaque iron ore $(5-15 \%)$. The matrix content ranges from $46 \%$ to $63 \%$ and contains volcanic glass and microlite and crystallite.

A composition of dacite-andesite is suggested for the samples based on their mineralogical characteristics, namely, lack of olivine, pyroxene and K-feldspar; and existence of amphibole and biotite in addition to minor amount of quartz, and porphyric texture. 

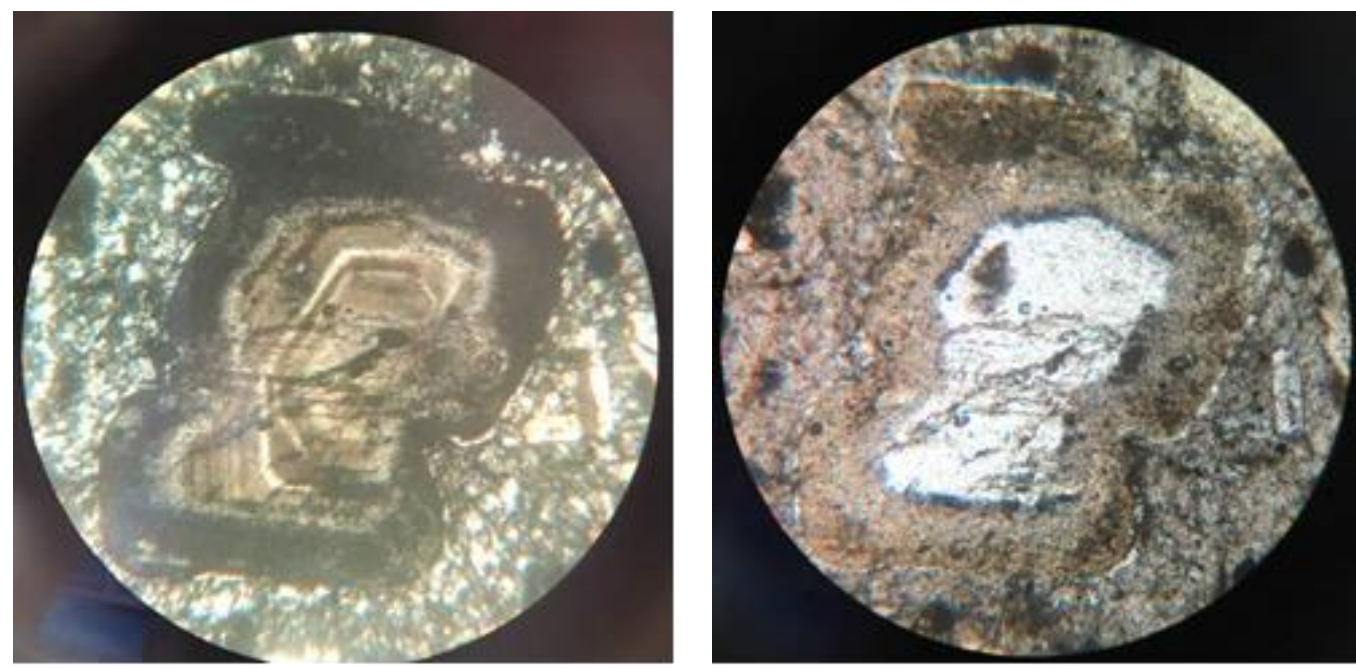

Figure 7: Oscillatory zoning and sieve texture. A) X Nicol, b) / Nicol, Scale bar is $0.6 \mathrm{~mm}$
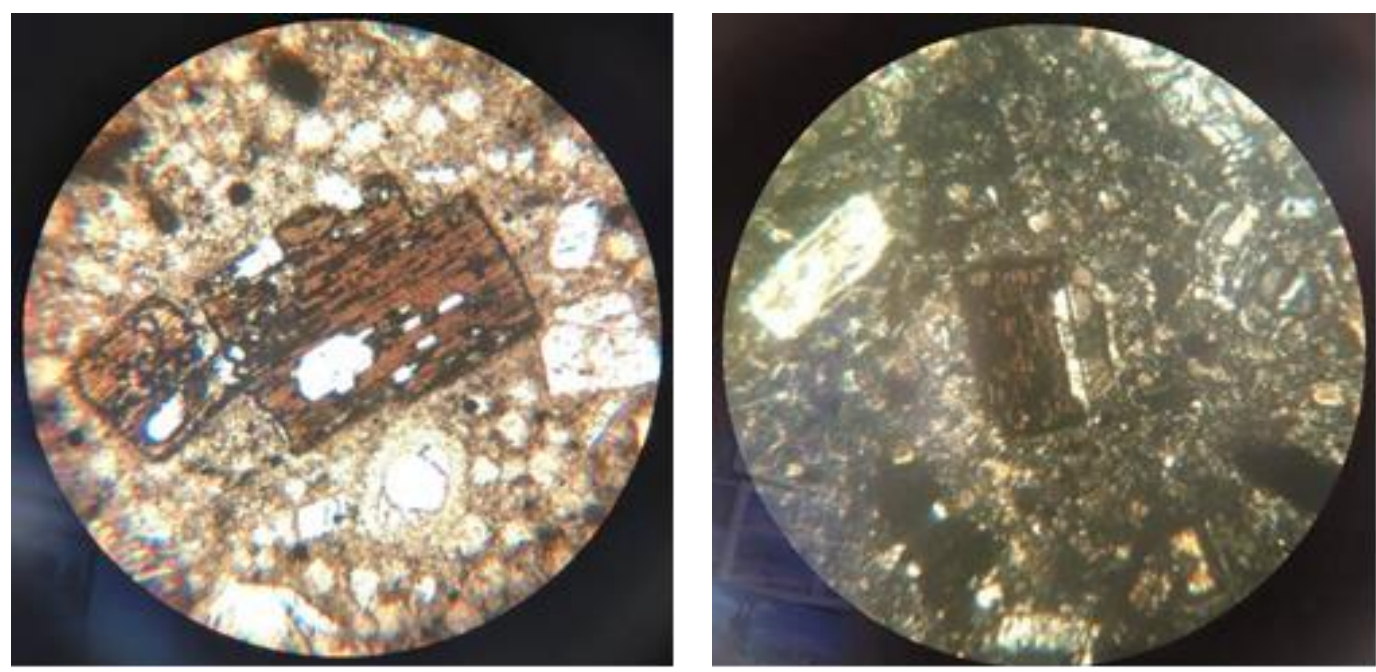

Figure 8: a) Biotite contains opacitic rim and resorption by plagioclase. / Nicol

b) The plagioclase develops next to (resorbed) biotite. X Nicol, Scale bar is $0.6 \mathrm{~mm}$
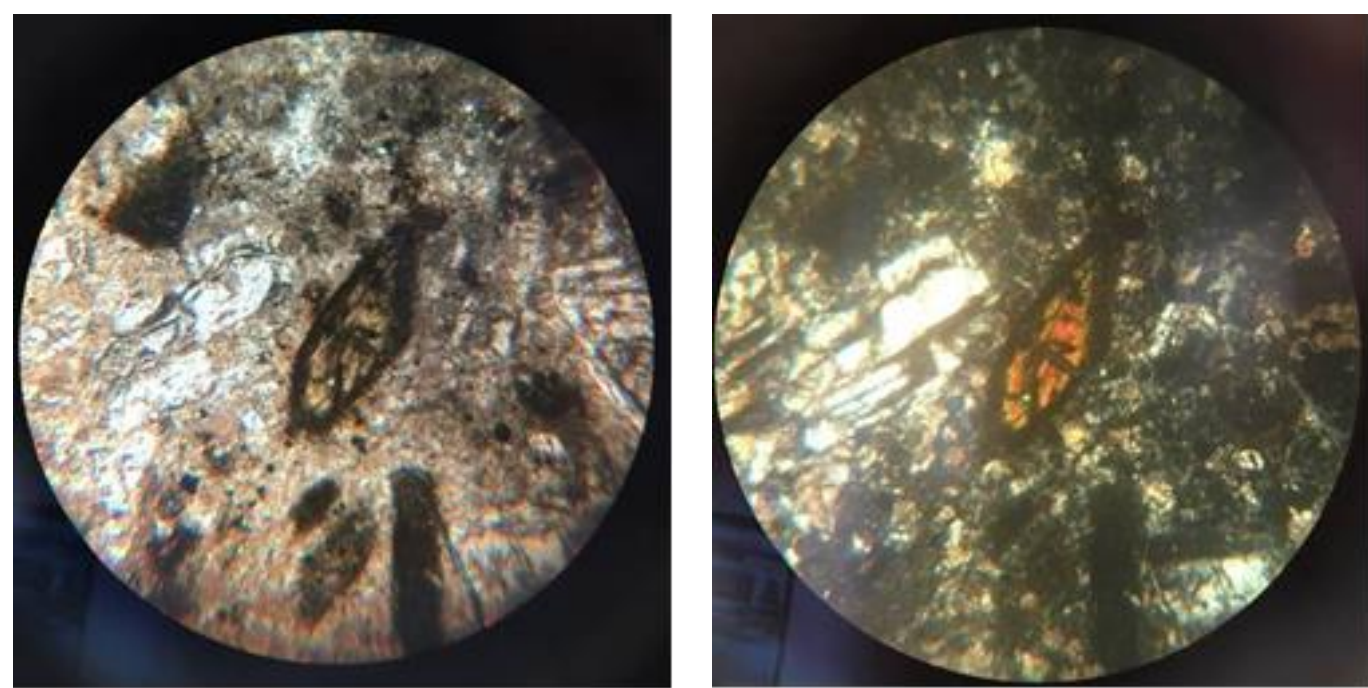

Figure 9: amphibole with opaque rim. Scale bar is $0.6 \mathrm{~mm}$ a) / Nicol, b) X Nicols 
The plagioclase phenocrysts $(2.5-6 \mathrm{~mm})$, show albite, albite-Carlsbad twinning, and oscillatory zoning with sieve structures (Figure 6). In some samples, the plagioclase crystals were granulated along its edge due to cataclastic process. The biotite (1.5-4 mm) exhibits strong pleochroism in the shades of brown colour and contains euhedral plagioclase crystals as an inclusion. The plagioclase may develop next to biotite by replacement. It is altered to chlorite and opaque iron ore. The amphibole exhibits strong pleochroism in the shade of green crystals. Biotite shows destabilization textures such as resorption by plagioclase (Figure $7 \mathrm{~b}$ ). Both the amphibole and biotite may have opaque iron rim (Figure 7, 8). High content opaque iron ore is possibly resulted from intensive alteration. It forms sometimes as hexagonal crystals $(2 \mathrm{~mm})$. Minor epidote occurs in the samples. Accessory apatite crystals develop as needles, indicating chilling of the magma developed in a "quenching" environment as the magma is quickly cooled, which symbolizes significant indication for the magma mixing process [19], which is supported by existence of sieve texture in plagioclase.

\section{CONCLUSON AND DISCUSSIONS}

Around İnlice area (Konya), several circular to ellipsoidal volcanic plugs determined in a small area on the basis of field relations. They crop out within lava dome, with heights ranging from a few meters to $>50$ meters. Plug -4 and -5 joint system may develop mostly in NE direction, which is cut predominantly by faults with N-S direction.

Petrographic studies show that the samples are possibly dacite-andesite in composition, with phenocrysts of plagioclase (20-25\%), biotite (10\%), quartz (1-2\%), amphibole (1$2 \%$ ), and opaque iron ore $(5-15 \%)$ in a hypocrystalline porphyric texture. The samples have also some disequilibrium structures such as sieve texture in plagioclase, and acicular apatites, suggestive of magma mixing.

The plug and plug-like occurrences are important since no detail study exist in the literature for the plug occurrence in Turkey, and required further detail studies, such as joint measurement and mineralogical and geochemical studies.

\section{REFERENCES}

[1] Ritchie D. The encyclopedia of earthquakes and volcanoes, New York, Facts on File, 1994.

[2] Delaney PT, Pollard DD. Deformation of host rocks and flow of magma during growth of minette dikes and breccia-bearing intrusions near Ship Rock, New Mexico Professional Paper (ed.) (1981).

[3] Marsh BD. Magma chambers. In S H.; H B.; M S; R H.;S J (Eds.), The encyclopedia of volcanoes (2nd edn ed., pp. 185-201) ( 2015). Elsevier Academic Press.

[4] Gocmengil G; Karacik Z; Genc SC, Billor MZ. Ar-40-Ar-39 geochronology and petrogenesis of postcollisional trachytic volcanism along the Izmir-Ankara-Erzincan Suture Zone (NE, Turkey), Turkish Journal of Earth Sciences, vol. 27, 1, pp.1-31, 2018.

[5] Akal C. K-richterite-olivine-phlogopite-diopside-sanidine lamproites from the Afyon volcanic province, Turkey, Geological Magazine, vol. 145, 4, pp.570-585, 2008.

[6] Kuşçu M, Tuncay EB. (2018). Trace Element Contents of Pliocene-Quaternary Potassic Gölcük Pumices (Isparta-Turkey): May the Gölcük Volcanic Rocks be Potential Th Source? . Paper presented at the Jeokimya Sempozyumu / 8. Geochemistry Symposium 2-6 Mayıs 2018, Antalya. 
[7] Bozkurt E; Winchester JA; Ruffet G, Rojay B. Age and Chemistry of Miocene Volcanic. Rocks from the Kiraz Basin of the Kucuk Menderes Graben: Its Significance for the Extensional Tectonics of Southwestern Anatolia, Turkey', Geodinamica Acta, vol. 21, 5-6, pp.239-257, 2008.

[8] Kocyigit A, Erol O. A tectonic escape structure: Erciyes pull-apart basin, Kayseri, central Anatolia, Turkey, Geodinamica Acta, vol. 14, 1-3, pp.133-145, 2001.

[9] Temel A; Gundogdu MN, Gourgaud A. Petrological and geochemical characteristics of Cenozoic high-Kcalc-alkaline volcanism in Konya, Central Anatolia, Turkey Journal of Volcanology and Geothermal Research, vol. 85, 1-4, pp.327-354, 1998.

[10] Keller J; Jung D; Burgath K, Wolff F. Geologie und petrologie des Neogenen kalkalkalivulkanismus von Konya (Erenler Dağ - Alaca Dağ - Massiv, Geologisches Jahrbuch Hessen, vol. 25, pp.37-117, 1977.

[11] Kurt H; Özkan AM, Kocak K. Geology, Petrography And Geochemistry Of The Subduction Related Volcanic Rocks, West Of Konya, Central Anatolia, Türkiye Jeoloji Bülteni, vol. 46, 2, pp.39- 512003.

[12] Uyanık C, K. K. ( 2016). Geochemical characterıstics of the Erenlerdag1 volcanics, Konya, Central Turkey. . Paper presented at the the 14th International Congress, Thessaloniki, May 2016., Thessaloniki, Greece.

[13] Kocak K, Zedef V. Geochemical Characterisics Of The Lava Domes in Yatagan Village And Sağlik Town, From Erenlerdagı (Konya, Central Turkey) Volcanites, Acta Geobalcanica, vol. 2, 1, pp.7-19, 2016.

[14] Asan K, Erturk MA. First Evidence of Lamprophyric Magmatism from the Konya Region, Turkey: a Genetic Link to High-K Volcanism, Acta Geologica Sinica-English Edition, vol. 87, 6, pp.1617-1629, 2013.

[15] Koçak K. (2016). Geochemical characteristics of the mafic enclaves and their hosts from Neogene Erenlerdagı volcanites, around Yatagan village and Sağlık town (Konya), central Turkey. Paper presented at the 14th Intern. Congress, Thessaloniki, May 2016, Thessaloniki.

[16] Koçak K. (2012). Geochemical characteristics of the Late Miocene to Pliocene Ulumuhsine sill of the Erenlerdagi volcanics, Konya, Central Turkey, . Paper presented at the Ore potential of alkaline, kimberlite and carbonatite magmatism, 2012, 14-18 September, Sudak, Ukraine.

[17] Zürcher L; A.A. B; Hammarstrom JM, et al. Porphyry copper assessment of the Tethys region of western and southern Asia: U.S. Geological Survey Scientific Investigations Report In S JEWELL;SM Kimball (Eds.), Global Mineral Resource Assessment (Vol. 2010-5090-V, pp. 232 p., and spatial data, http://dx.doi.org/210.3133/sir20105090V.) (2015). U.S. Department of the Interior, U.S. Geological Survey.

[18] Hall DJ; Foster RP; Yildiz B, Redwood SD. The Inlice High-sulphidation Epithermal Gold Discovery: Defining a Potential New Gold Belt in Turkey, Digging Deeper, Vols 1 and 2, vol., pp.113-116, 2007.

[19] Wyllıe PJ; Cox KG, Biggar GM. The Habit of Apatite in Synthetic Systems and Igneous Rocks, Journal of Petrology, vol. 3, 2, pp.238-243, 1962 